\title{
THE POTENTIAL OF ACTIVE COMPOUNDS Polyscias Scutellaria AS INHIBITORS IN CERVICAL CANCER WITH VIRTUAL SCREENING APPROACH
}

\author{
Muhammad Rizki Kurniawan'1, Aji Humaedi² \\ 'Study Program of Medical Laboratory Technology, Faculty of Science and Technology, Binawan \\ University, Jakarta, Indonesia \\ 2Study Program of Pharmacy, Faculty of Science and Technology, Binawan University, Jakarta, \\ Indonesia \\ E-mail:kurniawan@binawan.ac.id.
}

Received : 15 Februari 2021; revised : 16 Maret 2021; accepted : 22 April 2021

\begin{abstract}
THE POTENTIAL OF ACTIVE COMPOUNDS Polyscias Scutellaria AS INHIBITORS IN CERVICAL CANCER WITH VIRTUAL SCREENING APPROACH Cervical cancer is a gynecologic disease that has a high enough malignancy that affects women. In cervical cancer, it is known that the overexpression of $\mathrm{Bcl}-2$ protein is $14.3 \%$ in non-invasive cervical carcinoma and $65.2 \%$ in invasive cervical carcinoma. The $\mathrm{Bcl}-2$ protein is an important regulator of growth and differentiation pathways. $\mathrm{Bcl}-2$ has anti-apoptotic activity but permeabilization occurs through the mitochondrial pathway, triggering the release of cytochrome c, which then interacts with Apaf-1 for caspase- 9 activation and apoptosis occurs. This study aims to determine the mechanism of inhibition of overexpression of Bcl-2 protein by bioactive compounds from the Polyscias scutellaria plant with a virtual screening approach through in silico studies. The in silico study was carried out with the stages of tracking molecular targets, preparation, optimization, simulation and analysis of docking results. The results of the docking analysis showed that the bioactive compounds of the mangkokan plant provided inhibitory activity with gibbs energy values of $-6.07,-5.18,-5.43$ and -6.02 , respectively. Thus the bioactive compounds from the mangkokan plant have potential as Bcl-2 inhibitors in cervical cancer.
\end{abstract}

Key words : Cervical Cancer, Polyscias scutellaria, Virtual Screening, Docking Simulation

\begin{abstract}
ABSTRAK
POTENSI SENYAWA AKTIF Polyscias Scutellaria SEBAGAI INHIBITOR KANKER SERVIKS DENGAN PENDEKATAN VIRTUAL SCREENING Kanker serviks adalah penyakit ginekologik yang memiliki tingkat keganasan yang cukup tinggi yang menyerang wanita. Pada kanker serviks diketahui over ekspresi protein Bcl-2 sebesar 14,3\% pada karsinoma serviks non invasive dan 65,2\% pada karsinoma serviks invasive. Protein Bcl-2 merupakan regulator penting dalam jalur pertumbuhan dan diferensiasi. Bcl-2 memiliki aktivitas anti-apoptosis tetapi melalui jalur mitokondria terjadi permeabilisasi sehingga memicu pelepasan sitokrom c, yang kemudian berinteraksi dengan Apaf-1 untuk aktivasi kaspase-9 dan terjadi apoptosis. Penelitian ini bertujuan untuk mengetahui mekanisme inhibisi ekspresi berlebih dari protein Bcl-2 oleh senyawa bioaktif dari tanaman Polyscias scutellaria (mangkokan) dengan pendekatan virtual screening melalui studi in silico. Studi in silico dilakukan dengan tahapan penelusuran target molekular, preparasi, optimasi, simulasi dan analisis hasil docking. Hasil analisis docking menunjukkan senyawa bioaktif tanaman mangkokan memberikan aktivitas inhibisi dengan nilai energi gibbs sebesar -6,07, -5,18, -5,43 dan -6,02 berturut-turut. Dengan demikian senyawa bioaktif dari tanaman mangkokan memiliki potensi sebagai inhibitor Bcl-2 pada kanker serviks.
\end{abstract}

Kata kunci : Kanker Serviks, Polyscias scutellaria, Virtual Screening, Simulasi Docking

\section{INTRODUCTION}

Cancer is a disease involving the abnormality in cell growth, including women's reproductive systems such as cervix. Cervical cancer is a gynaecological disease is quite deadly. The data from Globocan International Agency for Research on Cancer (IARC) in 2012 
reported that cervical cancer is the world's fourth most deadly disease (Ferlay et al.,2015). The Riskesdas data from 2013 also stated that the cancer prevalence in Indonesia was 1.8 in every 1000 women (Riset Kesehatan Dasar,2018). In Indonesia, cervical cancer is the second highest killer disease among women after the breast cancer. The mortality profile shows that out of the 92,000 deaths among women with cancer, the $14.1 \%$ were due to cervical cancer(World Health Organization, 2020).

In cervical cancer, the overexpression of $\mathrm{Bcl}-2$ protein is known to be $14.3 \%$ in noninvasive cervical carcinoma and $65.2 \%$ in invasive cervical carcinoma (Giarnieri et al.,2000). The BCL-2 protein family is an important regulator of the intrinsic pro-apoptotic and anti-apoptotic pathways. Pro-apoptosis includes protein Bax, Bak, and Bim, while antiapoptosis consists of $\mathrm{Bcl}-2, \mathrm{Bcl}-\mathrm{XL}, \mathrm{Bcl}-\mathrm{w}$, and Mcl-1 (Campbel et al.,2018). Bcl-2 has an antiapoptosis activity and is expressed in various types of cancer, especially cervical cancer (Xu et al.,2018). Several studies suggest that the anti-apoptotic function of $\mathrm{Bcl}-2$ is present in mitochondria as well as the endoplasmic reticulum mediated by homeostatic and dynamic effects on intracellular Ca2+ (Hirata et al.,2012). Mitochondria are the main executor of apoptosis associated with $\mathrm{Bcl}-2$ protein, which in turn cause permeabilization of the outer membrane of the mitochondria. This results in the release of cytochrome c, which then interacts with Apaf1 that triggers the caspase- 9 activation and leads to apoptosis (Wang et al.,2014). The interaction of cytotoxic compounds with $\mathrm{Bcl}-2$ protein occurs mainly in the $\mathrm{BH} 3$ domain which can cause cell death or apoptosis (Thomas et al., 2013).

Currently, anticancer compounds derived from natural products are abundant because of their wide chemical diversity, physicochemical distribution, and high biological activity in inhibiting cancer growth (Newman \& Giddings, 2014) (Fang et al., 2018). The results of the study of gallic acid and their derivatives provide an in-silico inhibition of BRAF protein in colon cancer (Humaedi et al., 2016). Furthermore, curcumin provide excellent inhibitory effects on cervical cancer cells through inhibition of telomerase activity, RAS and ERK signalling, cyclin D1, Cox-2, iNOS and mitochondrial activity (Madden et al.,2009). The study of Bai et al, 2015 showed that bioactive flavonoid from various natural plants, namely butein, have an inhibitory effect on migration, invasion, and induction of apoptosis in many cancer cells, especially cervical cancer (Bai et al.,2015).

Mangkokan (Polyscias scutellaria) is known as a medicinal plant by the general public. The components of stems, leaves, fruits, and roots have bioactive compounds that are used for the treatment of various diseases. Generally it contains a group of substances such as flavonoids, aurones, chalcones, anthocyanins and anthocyanidins (Kurniawan et al., 2020). The virtual screening approach with in silico studies is one of the quick and easy steps to discover the potential of new compounds as anticancer. At this study, we identified a natural compound from the mangkokan plant (Polyscias scutellaria) which has potential as an inhibitor in cervical cancer by targeting the protein macromolecule Bcl-2.

\section{MATERIALS AND METHODS}

\section{Equipment and Materials}

The equipment used in this study silico molecular docking was carried out using an Intel core i5-4570 computer with 4 GB of RAM. Offline software used is MarvinSketch 15.5.11, Chimera 1.10.2, pymol 2.3.3, Rasmol 2.7.5, Ligplot 2.1 and Autodock 4.2. The materials used were the bioactive compounds of Mangkokan Plants (Polyscias scutelaria) and macromolecular

https://www.rcsb.org/structure/4AQ3 with code targets 4AQ3 for BCL2.

\section{Methods}

This research was conducted at the Computing Laboratory of Binawan University. The research process consists of 5 stages as follows: arranging the target structure of the active compound derived from Polyscias scutellaria, researching macromolecular targets for molecular docking, preparing ligands and receptors, simulating docking between macromolecules and ligands, and analyzing docking results.

\section{Research Stages}

The preparation of the target structure of the mangkokan plant bioactive compound (Polyscias scutellaria) includes searching, downloading, optimization and separation of non-standard residues. The following steps macromolecular target tracking was downloaded from the RSCB Web with code $4 A Q 3$ for BCL2. The next optimization was done using UCSF Chimera. Ligand preparation, namely the arrangement of ligands includes making 2D structures, changing the structure to $3 D$, and adding hydrogen atoms and Gasteiger energy. The next stage was making the Grid File Parameter (GPF) file and the Docking Paramater File (DPF) macromolecular complex with ligands used by Autodock 4.2 software. Furthermore, the docking simulation process between macromolecules and ligands which is 
operated using the "commond prompt" program produces a file with the formar file * .glg for GPF and ${ }^{*}$.dlg to apply for DPF. The last stage is the analysis of the docking simulation results.

\section{RESULTS AND DISCUSSION}

\section{The Molecular Characteristics of Test Ligand Compounds}

In this study, the identification of bioactive compounds of mangkokan plants (Polyscias scutellaria), namely kaempferol, myricetin, quercetin and 3- $\beta$-[O-aG55lphaLrhamnopyranosyl-(1-2)-

aarabionopyranosyl)oxy]-16- a hydroxyolean12-en-28-oic acid (Johnson-Ajinwo, O. R., 2017) et al., 2020). and comparison ligands (Figure 1) were in the form of molecular weight, cLog $p$, the number of hydrogen donors, and the number of hydrogen acceptors using the Ligandscout software. The results of the identification of characteristics are obtained in table 1 and will then be used as inhibitor compounds in in silico molecular docking studies.

Tabel 1. The Characteristics of Test Ligands

Compound and Comparison Ligands Compound

\begin{tabular}{cccc}
\hline $\mathrm{N}$ & Compound & Molecu cLo Numb Numbe \\
$\mathrm{o}$ & $\begin{array}{c}\text { lar gP er of } \mathrm{r} \text { of } \\
\text { weight }\end{array}$ & hydrog hydrog
\end{tabular}

en en

donors accept

\begin{tabular}{|c|c|c|c|c|}
\hline & & & & ors \\
\hline 1 Kaemferol & 286 & 2.46 & 4 & 6 \\
\hline 2 Myricetin & 318 & 1.85 & 6 & 8 \\
\hline 3 Quercetin & 302 & 2.16 & 5 & 7 \\
\hline 4 3- $\beta$-[O-aG55lpha- & 747 & 4.16 & 7 & 10 \\
\hline Lrhamnopyranosyl & & & & \\
\hline$-(1-2)-$ & & & & \\
\hline aarabionopyranos & & & & \\
\hline yl)oxy]-16- & & & & \\
\hline hydroxyolean-12- & & & & \\
\hline en-28-oic acid & & & & \\
\hline 5 Topotecan & 502 & 4.13 & 6 & 10 \\
\hline (Comparison & & & & \\
\hline Ligands) & & & & \\
\hline
\end{tabular}

The ligands used in the in-silico molecular docking study against the target protein Bcl-2 (PDB: 4AQ3; figure 2) used the protein database

access

at

https://www.rcsb.org/structure/4AQ3 were carried out by initial screening that met Lipinski's rules, namely molecular weight $<500$ grams $/ \mathrm{mol}$, number of hydrogen bonded proton donor groups $<5$, total hydrogen bond proton acceptor group $<10$, logarithmic value of the partition coefficient in water and 1-octanol $<5$ (Tice, 2001). Ligands that meet these rules are considered to have the potential to enter the cell membrane and be absorbed by the body.

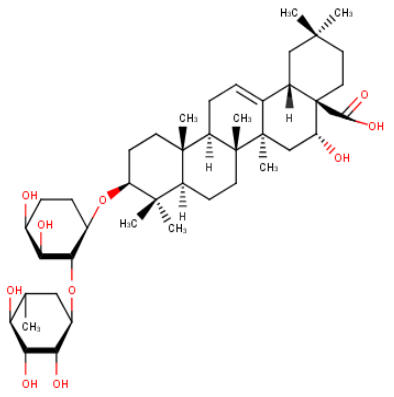

1<smiles>O=c1c(O)c(-c2cc(O)c(O)c(O)c2)oc2cc(O)cc(O)c12</smiles><smiles>O=c1c(O)c(-c2ccc(O)c(O)c2)oc2cc(O)cc(O)c12</smiles>

4<smiles>O=c1c(O)c(-c2ccc(O)cc2)oc2cc(O)cc(O)c12</smiles>

2

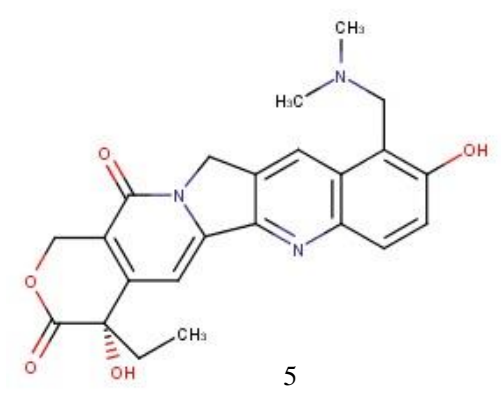

Figure 1. Structural Design of Polyscias scutellaria Active Compound and Its Derivates and Comparative Ligands 


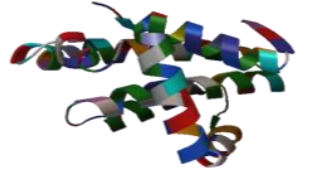

Figure 2. Structure of Bcl-2

The bioactive compounds from the Polyscias scutellaria plant and their derivatives used in this study have been selected according to the Lipinski rules (Table 1) so that these ligands are considered to have high bioavability potential for the body. Bioavability refers to the ability of a drug to be absorbed and circulated in the body (Sathishkumar et al., 2012).

\section{An Analysis and Visualization of Docking Simulation Results}

In silico molecular docking studies were carried out to evaluate the effect of the ligand on Bcl-2 macromolecules. The Gibbs energy reflects the energy interactions between the ligand-protein complexes and those with the lowest energy show the more stable interactions. The docking results for bioactive compounds of mangkokan plants and comparative ligands (anticancer drugs) can be seen in Table 2.

Table 2. The Gibbs Energy $(\mathrm{kkal} / \mathrm{mol})$, and its derivatives

\begin{tabular}{|c|c|c|}
\hline No & Compound Name & $\begin{array}{c}\text { Gibbs } \\
\text { Energy } \\
(\Delta \mathrm{G}) \\
\text { (kkal/mol) }\end{array}$ \\
\hline 1 & $\begin{array}{l}\text { 3- } \beta \text {-[O-aG55lpha- } \\
\text { Lrhamnopyranosyl-(1-2)- } \\
\text { aarabionopyranosyl)oxy]- } \\
\text { 16- a hydroxyolean-12-en- } \\
\text { 28-oic acid }\end{array}$ & -6.07 \\
\hline 2 & Quercetin & -5.18 \\
\hline 3 & Myricetin & -5.43 \\
\hline 4 & Kaemferol & -6.02 \\
\hline 5 & $\begin{array}{l}\text { Topotecan (Comparison } \\
\text { Ligands) }\end{array}$ & -6.40 \\
\hline
\end{tabular}

The docking data in table 2 shows that the mangkokan plant compounds gave varying $\Delta G$ values. Mangkokan plant compounds have the potential for inhibitory activity against cervical cancer $\mathrm{Bcl}-2$ protein macromolecules as antiproliferation and apoptosis induction with $\Delta G$ values of $-6.07,-5.18,-5.43,-6.02$ and $-6,40$ $\mathrm{kkal} / \mathrm{mol}$ respectively. The mangkokan plant compound (Polyscias scutellaria) which provides the best inhibitory activity against the Bcl-2 protein is Polyscias scutellaria. In addition to $\Delta G$, another indicator of docking results that shows the inhibitor standard between ligandprotein complexes is the inhibition constant (Ki), the number of hydrogen bonds and electrostatic energy can be seen in Table 3 .

Table 3. Simulation results of docking test ligands and comparison ligands at the Androgen receptor

\begin{tabular}{|c|c|c|c|c|}
\hline $\begin{array}{l}\mathrm{N} \\
\mathrm{O}\end{array}$ & Compound name & $\begin{array}{c}\mathrm{Ki} \\
(\mu \mathrm{M})\end{array}$ & $\begin{array}{l}\sum \mathrm{I} \\
\mathrm{H}\end{array}$ & $\begin{array}{c}\text { Electrost } \\
\text { atic } \\
\text { Energy }\end{array}$ \\
\hline 1 & $\begin{array}{l}\text { 3- } \beta \text {-[O-aG55lpha- } \\
\text { Lrhamnopyranosy } \\
\text { I-(1-2)- } \\
\text { aarabionopyranos } \\
\text { yl)oxy]-16- a } \\
\text { hydroxyolean-12- } \\
\text { en-28-oic acid }\end{array}$ & $\begin{array}{c}35.3 \\
8\end{array}$ & 3 & -0.46 \\
\hline 2 & Quarcetin & $\begin{array}{c}160 \\
12\end{array}$ & 3 & -0.008 \\
\hline 3 & Myrcetin & $\begin{array}{c}104 \\
31\end{array}$ & 2 & -0.06 \\
\hline 4 & Kaemferol & $\begin{array}{c}38.9 \\
8\end{array}$ & 2 & -0.12 \\
\hline 5 & $\begin{array}{l}\text { Topotecan } \\
\text { (Comparison } \\
\text { Ligand) }\end{array}$ & $\begin{array}{c}38.8 \\
0\end{array}$ & 0 & 0.90 \\
\hline
\end{tabular}


Inhibition constant is an important aspect that must be considered in ligand and receptor interactions because it is related to binding affinity. A lower affinity value indicates that a compound requires less energy to interact with the receptor. Thus, a lower binding affinity value has a greater potential to be able to interact with the target protein (Pangastuti et al., 2016)

In silico molecular docking studies have a good indicator when comparing the Gibbs energy value $(\Delta G)$, inhibition constant, and the number of hydrogen interactions as a standard inhibitor. Strong complex bonds are formed with a low Gibbs energy value $(\Delta G)$, an inhibition constant and a large number of hydrogen interactions. As seen in tables 1 and 2, according to the criteria of a good inhibitor, 3- $\beta$-[O-aG55IphaLrhamnopyranosyl-(1-2)-

aarabionopyranosyl)oxy]-16- a hydroxyolean12-en-28-oic acid(1) and kaempferol with Gibbs energy $(\Delta G)$, inhibition constant, number of interactions, and hydrogen electrostatic energy for 3- $\beta$-[O-aG55Ipha-Lrhamnopyranosyl-(1-2)aarabionopyranosyl)oxy]-16- $\alpha$ hydroxyolean12-en-28-oic acid and kaempferol in table 3 are $-6.01 \mathrm{kkal} / \mathrm{mol}, 35.38,3$, and -0.46 respectively. Topotecan compounds as comparison ligands provide a strong activity with Gibbs energy $(\Delta G)$, inhibition constant, number of interactions, and hydrogen electrostatic energy being $38.80,0$, and 0.90 .

Of the four test ligands, the bioactive compound 3- $\beta$ - [O-aG55lphaLrhamnopyranosyl- (1-2) - aarabionopyranosyl) oxy] -16- a hydroxyolean-12-en-28-oic acid, has better potential as an inhibitor against the target protein $\mathrm{Bcl}-2$ in cervical cancer with a value of $\Delta \mathrm{G}-6.07 \mathrm{kkal} / \mathrm{mol}$, Ki $35.38 \mu \mathrm{M}$ and electrostatic energy of -0.46 whereas compared to the comparator ligands the value of $\Delta G$ was slightly larger, it is likely that this is due to the number of alkyl groups, $\mathrm{OH}$, and benzene which affect the binding affinity.
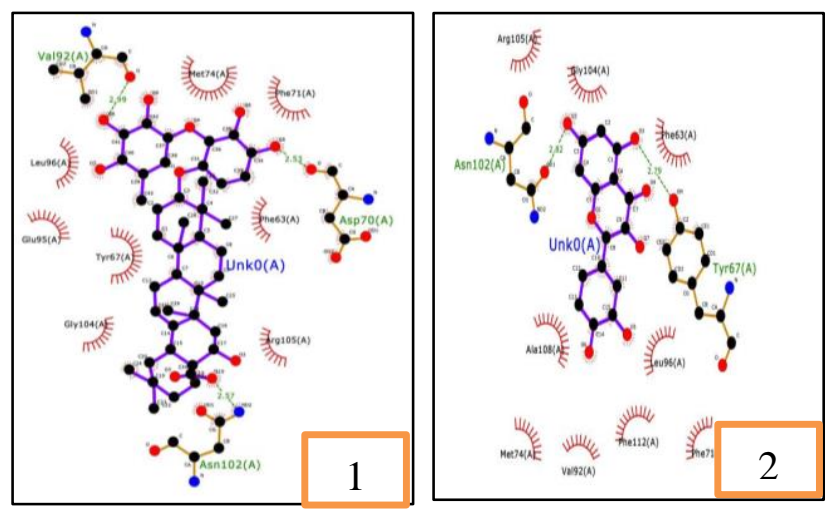
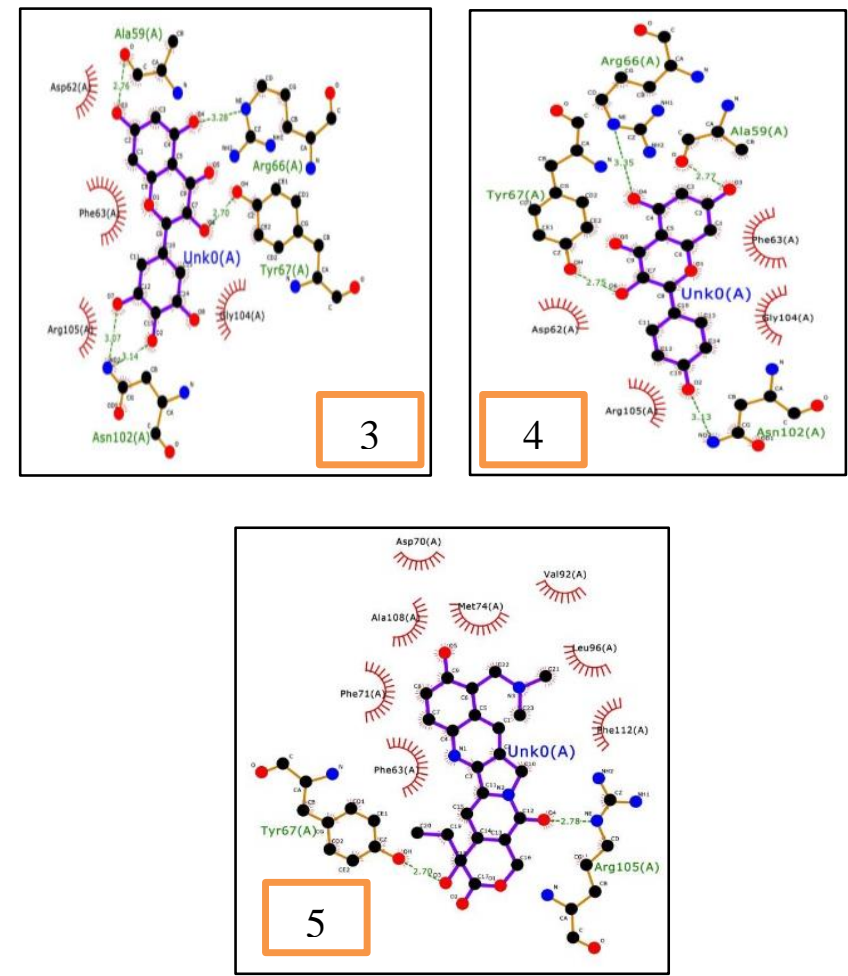

Figures 3. Intercation of Polyscias scutellaria ligands and their derivates (1. 3- $\beta$-[O-aG55Ipha-

Lrhamnopyranosyl-(1-2)- aarabionopyranosyl)oxy]16- $\alpha$ hydroxyolean-12-en-28-oic acid, 2. Quarecetin, 3. Mircyetin, 4. Kaemferol and comaprison ligands (5. Topotecan) with Bcl-2 macromolecules

Figure 3 shows that the interaction of the ligand with the $\mathrm{Bcl}-2$ macromolecule is bound to certain amino acids. Ligand 1 is bound to amino acids ASP70, VAL92 and ASN102; ligand 2 is bound to the amino acids TYR67 and ASN102; ligand 3 is bound to the amino acids ALA59, ARG66, TYR67 and ASN102; ligand 4 is bound to the amino acids ALA59, ARG66, TYR67 and ASN102; and ligand 5 is bound to the amino acids TYR67 and ARG105. In this interaction a strong enough hydrogen bond is formed with an average distance of $<3.5 \AA$ with the possibility of inhibition or apoptosis in cancer cells through binding to the $\mathrm{BH} 3$ domain. Research conducted by Sathiskumar et al (2012) showed a strong enough interaction between the ligands of (ginsenosides) natural compounds against Bcl-2 protein, namely the amino acids TYR67, GLU95, ARG142, ARG12, THR137, and ASN131. In addition, the natural compounds of the chalcone group provide a strong binding to 
the Bcl-2 protein in the amino acids ALA146 and ARG143 (Chen et al.,2017). There is a correlation, between chalcone and flavonoids which are secondary metabolites that have potential as anti-cancer properties. Using the same macromolecule, namely BCL-2, the mechanism of action is substantially the same.

\section{CONCLUSION}

The results of the virtual screening approach through in silico studies have shown that the bioactive compounds of mangkokan (Polyscias scutellaria), namely kaemferol, myrcetin, quarcetin and 3- $\beta$-[O-aG55IphaLrhamnopyranosyl-(1-2)-

aarabionopyranosyl)oxy]-16- a hydroxyolean-12en-28-oic acid is the most potential compound as candidates for cervical cancer drugs. Based on three important indicators that $\Delta G-6.07$ $\mathrm{kkal} / \mathrm{mol}, \mathrm{Ki} 35.38 \mu \mathrm{M}$ and $\Sigma \mathrm{IH}-0.46$. Virtual screening simulated the first step in the development of new drug candidate searches. Further research needs to be done in vitro to determine the potential for inhibition of cervical cancer cell lines.

\section{ACKNOWLEDGEMENTS}

This research was funded by the Ministry of Research and Technology Grant, National Research and Innovation Agency, with a contract number of 051/LL3/PG/2020.

\section{REFERENCES}

Bai, X., Ma, Y., \& Zhang, G. (2015). Butein suppresses cervical cancer growth through the PI3K/AKT/mTOR pathway. Oncology Reports, 33(6), 3085-3092. https://doi.org/10.3892/or.2015.3922

Campbell, K. J., \& Tait, S. W. G. (2018). Targeting BCL-2 regulated apoptosis in cancer. Open Biology, 8(5), 1-11. https://doi.org/10.1098/rsob.180002

Chen, G., Zhou, D., Li, X. Z., Jiang, Z., Tan, C., Wei, X. Y., Ling, J., Jing, J., Liu, F., \& Li, N. (2017). A natural chalcone induces apoptosis in lung cancer cells: 3D-QSAR, docking and an in vivo/vitro assay. Scientific Reports, 7(1), 1-10. https://doi.org/10.1038/s41598-017-113699

Ferlay, J., Soerjomataram, I., Dikshit, R., Eser, S., Mathers, C., Rebelo, M., Parkin, D. M., Forman, D., \& Bray, F. (2015). Cancer incidence and mortality worldwide: Sources, methods and major patterns in GLOBOCAN 2012. International Journal of Cancer, 136(5), E359-E386. https://doi.org/10.1002/ijc.29210
Giarnieri, E., Mancini, R., Pisani, T., Alderisio, M., \& Vecchione, A. (2000). Msh2, Mlh1, Fhit, p53, Bcl-2, and Bax Expression in Invasive and in Situ Squamous Cell Carcinoma of the Uterine Cervix 1. Clinical Cancer Research, 6, 3600-3606.

Hirata, H., Lopes, G. S., Jurkiewicz, A., GarcezDo-Carmo, L., \& Smaili, S. S. (2012). Bcl-2 modulates endoplasmic reticulum and mitochondrial calcium stores in PC12 cells. Neurochemical Research, 37(2), 238-243. https://doi.org/10.1007/s11064-011-0600-5

Humaedi, A., Arsianti, A., \& Radji, M. (2017). In Silico Molecular Docking Study of Gallic Acid and Its Derivatives as Inhibitor BRAF Colon Cancer. International Journal of ChemTech Research, 10(1), 310-315. http://www.rscb.org/pdb/

Madden, K., Flowers, L., Salani, R., Horowitz, I., Logan, S., Kowalski, K., Xie, J., \& Mohammed, S. I. (2009). Proteomicsbased approach to elucidate the mechanism of antitumor effect of curcumin in cervical cancer. Prostaglandins Leukotrienes and Essential Fatty Acids, 80(1), 9-18. https://doi.org/10.1016/j.plefa.2008.10.003

Newman, D. J., \& Giddings, L. A. (2014). Natural Products as Leads to Antitumor Drugs. Phytochemistry Reviews, 13(1), 123-137. https://doi.org/10.1007/s11101-013-9292-6

Pangastuti, A., Wulandari, A. M., Amin, A. Z., \& Amin, M. (2016). Mengungkap Potensi Senyawa Alami dari Cabai (Capsicum annuum L) Sebagai Agen Anti-Autism Melalui Teknik Reverse Docking. Prosiding Semnas Hayati IV, 123-129. http://www.rcsb.org

Rizki Kurniawan, M., Humaedi, A., \& Fitra Ritonga, A. (2020). Direct Investigation of Synthesis of Gold Nanoparticles Using Polyscias scutellaria Leaf Extract in the Hexane-Water System Using the Centrifugal Liquid MembraneSpectrophotometry Method. Jurnal Kimia Sains Dan Aplikasi, 23(7), 255-260. https://doi.org/10.14710/jksa.23.7

Rosa Johnson-ajinwo, O. (2017). Identification, Semi-Synthesis And Evaluation Of AntiOvarian Cancer Compounds From Plants Used In Traditional Medicines.

Sathishkumar, N., Sathiyamoorthy, S., Ramya, M., Yang, D. U., Lee, H. N., \& Yang, D. C. (2012). Molecular docking studies of antiapoptotic BCL-2, BCL-XL, and MCL-1 proteins with ginsenosides from Panax ginseng. Journal of Enzyme Inhibition and Medicinal Chemistry, 27(5), 685-692. https://doi.org/10.3109/14756366.2011.608 663

Thomas, S., Quinn, B. A., Das, S. K., Dash, R., 
Emdad, L., Dasgupta, S., Wang, X. Y., Dent, P., Reed, J. C., Pellecchia, M., Sarkar, D., \& Fisher, P. B. (2013). Targeting the Bcl-2 Family for Cancer Therapy. In Expert Opinion on Therapeutic Targets (Vol. 17, Issue 1, pp. 61-75). https://doi.org/10.1517/14728222.2013.733 001

Tice, C. M. (2001). Selecting the right compounds for screening: does Lipinski's Rule of 5 for pharmaceuticals apply to agrochemicals? Pest Management Science, 57, 3-16.
Wang, K., Zhu, X., Zhang, K., Zhu, L., \& Zhou, F. (2014). Investigation of Gallic acid induced anticancer effect in human breast carcinoma MCF-7 cells. Journal of Biochemical and Molecular Toxicology, 28(9), 387-393. https://doi.org/10.1002/jbt.21575

Xu, L., Xie, Q., Qi, L., Wang, C., Xu, N., Liu, W., Yu, Y., Li, S., \& Xu, Y. (2018). Bcl-2 Overexpression Reduces Cisplatin Cytotoxicity by Decreasing ERMitochondrial $\mathrm{Ca} 2+$ Signaling in SKOV3 cells. Oncology Reports, 39(3), 985-992. https://doi.org/10.3892/or.2017.6164 